\title{
MEMAKNAI KEMBALI \\ PENGANGGARAN BERBASIS KINERJA BERDASARKAN STUDI IMPLEMENTASI PENGANGGARAN SEKTOR PUBLIK
}

\author{
Ali Tafriji Biswan¹, Iklima Devi Grafitanti² \\ ${ }^{1}$ Politeknik Keuangan Negara STAN, ${ }^{2}$ Direktorat Jenderal Kekayaan Negara
}

\begin{abstract}
Budgeting practices that tend to add administrative work, are less flexible, and less accommodating are still challenges for the public sector. This study aims to review the meaning of performance-based budgeting in public sector based on a study of budgeting implementation at the Palangkaraya State Assets and Auction Services Office (KPKNL). The study was conducted qualitatively using an exploratory approach which was sharpened through observation, interviews, and theoretical analysis. The study results dismiss the old mindset that budgeting must increase from year to year, the deified behavior of the budget that there is no budget means a dead faint and the budget cannot be changed, and the assumption that the output of activities must be administrative and must exist beforehand. The study also supports that performance-based budgeting promotes better budget absorption and accountability.
\end{abstract}

\begin{abstract}
Abstrak
Praktik penganggaran yang cenderung menambah pekerjaan administratif, kurang fleksibel, kurang akomodatif masih menjadi tantangan bagi sektor publik. Penelitian ini bertujuan untuk meninjau kembali makna penganggaran berbasis kinerja pada organisasi sektor publik berdasarkan studi implementasi penganggaran pada Kantor Pelayanan Kekayaan Negara dan Lelang (KPKNL) Palangkaraya. Studi ini dilakukan secara kualitatif dengan menggunakan pendekatan eksploratif yang dipertajam melalui proses pengamatan, wawancara, dan telaah teoretis. Hasil studi menepis pola pikir lawas bahwa penganggaran harus bertambah dari tahun ke tahun, perilaku mendewakan anggaran bahwa tidak ada anggaran berarti kegiatan menjadi mati suri atau terhenti, anggaran yang tidak bisa diubah, serta anggapan bahwa hasil atau keluaran kegiatan harus bersifat administratif dan harus ada sebelumnya. Studi ini juga mendukung bahwa penganggaran berbasis kinerja mendorong kinerja penyerapan anggaran instansi pemerintah dan akuntabilitas anggaran yang lebih baik.
\end{abstract}

Keywords: akuntabilitas, penganggaran berbasis kinerja, sektor publik JEL Classification: H11, H61 


\section{PENDAHULUAN}

Diterbitkannya Undang-Undang Nomor 17 Tahun 2003 tentang Keuangan Negara, Undang-Undang Nomor 1 Tahun 2004 tentang Perbendaharaan Negara, UndangUndang Nomor 15 Tahun 2004 tentang Pemeriksaan Pengelolaan dan Tanggung Jawab Keuangan Negara, dan Undang-Undang Nomor 25 Tahun 2004 tentang Perencanaan Pembangunan Nasional merupakan awal dari reformasi di bidang penganggaran. Pada tahun 2004 pemerintah juga menerbitkan pengaturan yang lebih rinci tentang penganggaran melalui Peraturan Pemerintah Nomor 21 Tahun 2004 tentang Penyusunan Rencana Kerja dan Anggaran

Kementerian

Negara/Lembaga. Dalam peraturan tersebut diamanatkan bahwa penyusunan anggaran perlu dilakukan dengan pendekatan penganggaran berbasis kinerja (performance based budget). Penerapan penganggaran berbasis kinerja perlu didukung oleh penerapan anggaran terpadu (unified budget) dan kerangka pengeluaran jangka menengah (medium term expenditure framework).

Fokus penganggaran berbasis kinerja adalah tercapainya target kinerja dengan menggunakan sarana yang ada, yaitu anggaran. Konsep penyusunan anggaran sudah tidak ditekankan pada pertimbangan sumber daya atau input yang ada, namun pertimbangan lebih pada target kinerja yang akan dicapai. Dengan pergeseran fokus ini, diharapkan tercipta efisiensi dan efektivitas pelaksanaan kegiatan dengan menggunakan input yang tersedia.
Selain meningkatkan efisiensi dan efektivitas pelaksanaan anggaran pemerintah, penganggaran berbasis kinerja juga diharapkan meningkatkan akuntabilitas kinerja pemerintahan. Dalam penganggaran berbasis kinerja terdapat dua perspektif yaitu top-down dan bottom-up. Perspektif top-down berarti bahwa penganggaran dirancang oleh pemegang kebijakan tertinggi untuk kemudian dilaksanakan tiap unit kerja di bawahnya, sedangkan perspektif bottom-up berarti bahwa anggaran digunakan untuk melaksanakan kegiatan dalam rangka menghasilkan keluaran. Atas hasil keluaran tiap kementerian negara/lembaga (K/L), pada akhirnya penganggaran mendukung pencapaian program secara nasional.

Penganggaran berbasis kinerja secara nasional dapat dilihat melalui keterkaitan pengalokasian anggaran dengan Rencana Kerja Pemerintah (RKP). RKP membagi target kinerja yang harus dicapai ke dalam beberapa prioritas. Pencapaian target kinerja dalam prioritas merupakan tanggung jawab beberapa $\mathrm{K} / \mathrm{L}$, sehingga diperlukan suatu koordinasi antar K/L terkait. Kemudian prioritas tersebut dijabarkan lebih rinci dalam fokus prioritas yang berisikan kegiatan yang menjadi tanggung jawab tiap $\mathrm{K} / \mathrm{L}$, dilaksanakan dalam rangka tercapainya target kinerja prioritas.

Dengan adanya kinerja yang harus dicapai yang tercantum pada prioritas dan dirinci melalui fokus prioritas, proses pengalokasian anggaran secara nasional mengacu pada prioritas dan fokus prioritas tersebut. Di sisi lain, penerapan penganggaran berbasis kinerja pada tiap K/L dapat dilihat dari proses pengalokasian anggaran yang 
didasarkan pada program dan kegiatan masing-masing $\mathrm{K} / \mathrm{L}$ sesuai tugas dan fungsi yang diemban.

Studi penerapan penganggaran berbasis kinerja pada sektor publik umumnya mengambil objek umum, sehingga simpulannya mengarah pada penarikan simpulan umum hasil hitungan kuantitatif. Hal ini sangat bermanfaat memberikan panduan studi penganggaran berbasis kinerja ke arah yang lebih spesifik, yakni dunia riil. Kita ambil saja contoh hasil penelitian Sofyani dan Prayudi (2018) yang mengulas tentang penerapan anggaran berbasis kinerja pada pemerintah daerah, menyimpulkan bahwa semakin baik implementasi anggaran berbasis kinerja maka penyerapan anggaran akan berjalan baik pula. Selanjutnya penelitian oleh Krispahanripi (2017) tentang pengaruh penerapan anggaran berbasis kinerja terhadap akuntabilitas kinerja instansi pemerintah (Badan Pengelolaan Keuangan dan Aset Daerah), menyimpulkan bahwa anggaran berbasis kinerja berpengaruh signifikan terhadap akuntabilitas kinerja instansi pemerintah tersebut.

Secara garis besar, pengganggaran berbasis kinerja ini diharapkan mampu untuk menghubungkan pengalokasian anggaran dengan target kinerja, meningkatkan efisiensi dan transparansi dalam pelaksanaan kegiatan pemerintah, dan meningkatkan fleksibilitas dan akuntabilitas pemerintah dalam melaksanakan kegiatan, termasuk pengelolaan anggarannya. Oleh karenanya, studi ini diperlukan untuk meninjau kembali makna penganggaran berbasis kinerja pada dunia praktik. Studi ini mengambil objek implementasi penganggaran yang spesifik pada Kantor Pelayanan
Kekayaan Negara dan Lelang Palangkaraya. Studi ini diharapkan dapat menemukan kembali makna penganggaran berbasis kinerja dan mengatasi pola pikir penganggaran yang keliru atau tidak sejalan dengan penganggaran berbasis kinerja.

\section{TINJAUAN LITERATUR}

Organisasi sektor publik (pemerintah) dalam mencapai tujuannya merancang anggaran secara periodik. Anggaran menjadi kunci komponen dalam perencanaan. Selaras dengan Pedoman Penerapan Penganggaran Berbasis Kinerja (Bappenas, 2009), dalam menyusun anggaran, pemerintah mengacu pada tiga pilar sistem penganggaran yaitu penganggaran terpadu, penganggaran berbasis kinerja, dan kerangka pengeluaran jangka menengah (KPJM). Tiga pilar ini diharapkan membuat proses penganggaran semakin baik dan akuntabel.

Tidak dipungkiri bahwa hingga saat ini penganggaran berbasis kinerja masih menjadi primadona sistem penganggaran terbaik. Hal ini sesuai pendapat Mardiasmo (2009) bahwa performance budget pada dasarnya adalah sistem penyusunan dan pengelolaan anggaran dengan berorientasi pada pencapaian hasil atau kinerja. Mohammadipour (2014) menyebutkan bahwa, "Performancebased budgeting is one of the most important parts of budgeting system and plays essential role for the success of any organization" dalam pelaksanaannya, pendekatan pilar tersebut fokus pada penganggaran berbasis kinerja. Kedua pendekatan lainnya yaitu penganggaran terpadu dan KPJM 
mendukung penerapan penganggaran berbasis kinerja. Pendekatan anggaran terpadu merupakan prasyarat penerapan penganggaran berbasis kinerja, sedangkan pendekatan KPJM merupakan jaminan kontinuitas penyediaan anggaran kegiatan karena telah dirancang hingga tiga atau lima tahun ke depan. Ciri utama penganggaran berbasis kinerja adalah anggaran yang disusun dengan memperhatikan keterkaitan antara pendanaan (input) dan hasil yang diharapkan (outcome), sehingga dapat memberikan informasi tentang efektivitas dan efisiensi kegiatan.

Anwar Shah (2007) menyarankan bahwa penganggaran berbasis kinerja meningkatkan komunikasi budget actors, meningkatkan efisiensi dan efektivitas, memfasilitasi pengambilan keputusan lebih baik, meningkatkan transparansi dan akuntabilitas aktivitas pemerintah. Studi literatur Surianti dan Dalimunthe (2015) menyimpulkan bahwa rancangan penganggaran berbasis kinerja pemerintah RI selaras dengan teori penganggaran berbasis kinerja yang ada, yakni rancangan yang mengintegrasikan rencana jangka pendek, menengah, dan jangka panjang.

\section{Selaras dengan Pedoman} Penerapan Penganggaran Berbasis Kinerja (Bappenas, 2009), terdapat tiga prinsip dalam penganggaran berbasis kinerja. Prinsip pertama, output and outcome oriented yakni alokasi anggaran untuk tiap program atau kegiatan harus diarahkan untuk mencapai hasil dan keluaran sesuai dengan rencana yang telah ditetapkan agar penggunaan anggaran dapat menghasilkan manfaat yang sebesarbesarnya sehingga meningkatkan efisiensi pelaksanaan program atau kegiatan. Prinsip kedua, let the manager manages yakni dalam pelaksanaan program atau kegiatan, manajer berhak untuk menetapkan cara untuk mencapai target kinerja. Fleksibilitas manajer tetap harus memperhatikan aturan yang berlaku sehingga akuntabilitas pelaksanaan program atau kegiatan tetap terjaga. Prinsip ketiga, money follows function, function followed by structure yakni pengalokasian anggaran bagi suatu unit kerja didasarkan pada tugas dan fungsi unit kerja. Prinsip ketiga ini berkaitan dengan efektivitas pelaksanaan program atau kegiatan. Dengan demikian, atas dasar prinsipprinsip tersebut, tujuan penerapan penganggaran berbasis kinerja diharapkan menunjukan keterkaitan antara pendanaan dan prestasi kinerja yang akan dicapai (directly linkages between performance and budget), meningkatkan efisiensi dan transparansi dalam pelaksanaan (operational efficiency), dan meningkatkan fleksibilitas dan akuntabilitas unit dalam melaksanakan tugas dan pengelolaan anggaran (more flexibility and accountability).

Penyusunan anggaran berbasis kinerja memerlukan tiga komponen untuk masing-masing program dan kegiatan sebagaimana uraian Pasal 7 ayat (2) Peraturan Pemerintah No. 21 Tahun 2004 tentang Penyusunan Rencana Kerja dan Anggaran Kementerian Negara/Lembaga berupa:

a. Indikator Kinerja.

Indikator kinerja merupakan alat ukur untuk menilai keberhasilan suatu program atau kegiatan. Selaras dengan Pedoman Penerapan Penganggaran Berbasis Kinerja 
(Bappenas, 2009), indikator kinerja yang digunakan terdiri dari Key Performance Indicator (KPI) diterjemahkan sebagai Indikator Kinerja Utama Program (IKU Program) untuk menilai kinerja program, Indikator Kinerja Kegiatan (IK Kegiatan) untuk menilai kinerja kegiatan, dan Indikator Keluaran untuk menilai kinerja subkegiatan (tingkatan di bawah kegiatan).

b. Standar Biaya.

Standar biaya yang digunakan merupakan standar biaya masukan pada awal tahap perencanaan anggaran berbasis kinerja, dan nantinya menjadi standar biaya keluaran. Pengertian tersebut diterjemahkan berupa Standar Biaya Umum (SBU) dan Standar Biaya Khusus (SBK). SBU digunakan lintas kementerian negara/lembaga dan/atau lintas wilayah, sedangkan SBK digunakan oleh Kementerian Negara/Lembaga tertentu dan/atau di wilayah tertentu. $\mathrm{K} / \mathrm{L}$ diharuskan untuk merumuskan keluaran kegiatan beserta alokasi anggarannya. Alokasi anggaran tersebut dalam proses penyusunan anggaran mendasarkan pada prakiraan cara pelaksanaanya (asumsi). Pada saat pelaksanaan kegiatan, cara pelaksanaannya dapat saja berbeda sesuai dengan kondisi yang ada, sepanjang keluaran kegiatan tetap dapat dicapai. Sudut pandang pemikiran tersebut sejalan dengan prinsip let the manager manages. Dengan demikian, standar biaya merupakan alat bantu untuk penyusunan anggaran, merupakan kebutuhan anggaran yang paling efisien untuk menghasilkan keluaran, dan standar biaya dikaitkan dengan pelayanan yang diberikan oleh K/L (Standar Pelayanan Minimal).

c. Evaluasi Kinerja.

Evaluasi kinerja merupakan proses penilaian dan pengungkapan masalah implementasi kebijakan untuk memberikan umpan balik bagi peningkatan kualitas kinerja, baik dari sisi efisiensi dan efektivitas dari suatu program atau kegiatan. Cara pelaksanaan evaluasi dapat dilakukan dengan cara membandingkan hasil terhadap target (dari sisi efektivitas) dan realisasi terhadap rencana pemanfaatan sumber daya (dilihat dari sisi efisiensi). Hasil evaluasi kinerja merupakan umpan balik (feed back) bagi suatu organisasi untuk memperbaiki kinerjanya.

Rangkaian ketiga komponen membentuk suatu siklus penganggaran berbasis kinerja yakni penetapan sasaran strategis $\mathrm{K} / \mathrm{L}$; penetapan outcome, program, output, dan kegiatan; penetapan Indikator Kinerja Utama program dan indikator kinerja kegiatan; penetapan standar biaya; penghitungan kebutuhan anggaran; pelaksanaan kegiatan dan pembelanjaan; pertanggungjawaban; dan pengukuran dan evaluasi kinerja.

Pengaitan ukuran kinerja keluaran dan hasil tidak dapat dilepaskan dari konteks aktivitas yang menyerap sumber daya. Pendekatan Activitybased Costing $(A B C)$ bertujuan untuk meningkatan keandalan biaya. Hal ini penting dalam penganggaran mengingat tuntutan terhadap kinerja pengelolaan keuangan yang semakin ekonomis, efisien, efektif, akuntabel, dan transparan. Vakilifard, Zeynali, dan Mohammadipour (2010) menyebutkan 
bahwa implementasi penganggaran berbasis kinerja dikaitkan dengan analisis $A B C$ dapat mempermudah pencapaian tujuan penganggaran berbasis kinerja yang menekankan pada efisiensi, efektivitas, ekonomi, dan keluaran. Hal ini diperkuat oleh studi Fadilah (2009) yang menemukan bahwa penggunaan $A B C$ dalam penentuan analisis standar belanja akan dapat disusun Anggaran Pendapatan dan Belanja Daerah (APBD) yang efisien, efektif, dan hasil yang akan dicapai.

Berdasarkan tinjauan referensi tersebut, isu penganggaran tidak terlepas dari penyerapan anggaran yang efisien dan pencapaian tujuan kegiatan atau program yang efektif dengan dukungan anggaran. Maka, praktik penganggaran harus memperhatikan keduanya dengan pola penganggaran yang fleksibel dan akomodatif terhadap kebutuhan kinerja dan pelaksana kinerja.

\section{METODOLOGI PENELITIAN}

Metode yang digunakan dalam penelitian ini adalah pendekatan eksploratif yang didasarkan pada pengamatan, wawancara, dan telaah teoritis. Pendekatan ini digunakan dalam rangka menganalisis dan memahami penerapan penganggaran berbasis kinerja pada sektor publik. Berdasarkan pendekatan yang digunakan, organisasi sektor publik yang dijadikan objek penelitian adalah Kantor Pelayanan Kekayaan Negara dan Lelang (KPKNL) Palangkaraya, Direktorat Jenderal Kekayaan Negara. Dasar pemilihan objek dipengaruhi harapan peneliti untuk langsung melihat praktik penganggaran berbasis kinerja, mendapatkan makna studi praktik agar dapat memberikan masukan perbaikan penganggaran ke depan. Alasan pemilihan objek lainnya adalah kemudahan akses dalam melakukan penelitian dan ketersediaannya data sekunder sektor publik. Data yang dipakai adalah data primer dan data sekunder. Pengumpulan data primer dan data sekunder penganggaran pada sektor publik dilakukan untuk menghasilkan analisis penganggaran berbasis kinerja pada KPKNL Palangkaraya. Data primer didapatkan melalui keterlibatan peneliti dan wawancara dengan responden yaitu Kepala KPKNL Palangkaraya, Kasubbag Umum, dan staf yang menanganai langsung penganggaran di KPKNL Palangkaraya, dan staf Kantor Pusat DJKN seperti yang tercantum dalam Tabel 1.

Tabel 1. Daftar Nama Responden

\begin{tabular}{|l|l|}
\hline \multicolumn{1}{|c|}{$\begin{array}{c}\text { Nama } \\
\text { (Disamarkan) }\end{array}$} & \multicolumn{1}{c|}{ Jabatan } \\
\hline SG & Kepala Kantor \\
\hline HT & Kasubbag Umum \\
\hline NS & $\begin{array}{l}\text { Pelaksana/Operator } \\
\text { Penganggaran } \\
\text { KPKNL Palangkaraya }\end{array}$ \\
\hline GYF & Pelaksana Seksi PKN \\
\hline MA & $\begin{array}{l}\text { Bagian Perencanaan } \\
\text { Anggaran Kantor } \\
\text { Pusat DJKN }\end{array}$ \\
\hline
\end{tabular}

Sumber: Kantor Pelayanan Kekayaan Negara dan Lelang (KPKNL) Palangkaraya (data diolah, 2020)

Data sekunder didapat dari studi pustaka/literatur mulai dari buku, jurnal, publikasi, laporan yang dikeluarkan oleh pemerintah, seperti laporan keuangan maupun kinerja instansi pemerintah, dalam hal ini KPKNL Palangkaraya, serta peraturan- 
peraturan yang berhubungan dengan organisasi dan penelitian. Data sekunder yang digunakan adalah data umum yang mendukung penelitian sesuai tema. Periode penggalian data, observasi, dan wawancara adalah bulan Januari s.d Februari 2020.

Untuk mencapai tujuan penelitian tersebut, peneliti menempuh beberapa langkah, yakni review literatur dan pengumpulan data, analisis, serta penarikan simpulan. Review literatur dan pengumpulan data bertujuan untuk mendapatkan kerangka pemikiran yang tepat, kecukupan, dan kesesuaian data dan fakta agar menguatkan pembahasan hasil penelitian. Analisis menekankan integrasi data dan konseptual sehingga menjadi pembahasan utuh mengenai penerapan penganggaran berbasis kinerja sektor publik. Untuk sampai pada simpulan, penelitian didukung melalui pengolahan data oleh Eko Agus Purwanto (Direktorat Jenderal Pengelolaan Pembiayaan dan Risiko) dan Ronald Guntara (Direktorat Jenderal Bea dan Cukai). Langkah terakhir adalah penarikan simpulan, yakni bagaimana penganggaran berbasis kinerja dimaknai berdasar implementasi dunia praktik dan kontribusinya pada pengembangan. Penarikan simpulan juga mencerminkan sintesis peneliti diperkuat dari pernyataan narasumber (responden). Narasumber terpilih tersebut memiliki kepakaran di bidangnya, bahkan narasumber menjalankan proses bisnis penganggaran sesuai tugas dan fungsinya.

Penganggaran berbasis kinerja selanjutnya. Instansi pemerintah tidak akan mendapat upaya improve penganggaran berbasis kinerja terbaik tanpa melihat kondisi praktik, menganalisis, dan mengusulkan perbaikan-perbaikan.

\section{HASIL PENELITIAN DAN PEMBAHASAN}

Dalam menerapkan penganggaran berbasis kinerja, KPKNL memperhatikan tahapan yang dimulai dari perhatian pada visi misi Kementerian Keuangan. Visi misi Kementerian Keuangan itu menguatkan arah Direktorat Jenderal Kekayaan Negara (DJKN) (Unit Eselon 1) dan terlebih lagi secara spesifik pada KPNKL (Unit Eselon 3) dalam menyelenggarakan layanan kepemerintahan dan target organisasi. Maka, perumusan program dan kegiatan yang diukur dengan IKU merupakan implementasi yang nyata dilakukan. Tidak hanya tahapan, KPKNL memperhatikan pemeliharaan dokumen sumber tiap tahapan. Uraian kegiatan dan dokumen sumber yang dipelihara KPKNL Palangkaraya diikhtisarkan pada Tabel 2.

Analisis implementasi penganggaran berbasis kinerja di KPKNL Palangkaraya dilakukan dengan melihat proses implementasi berbasis kinerja serta kaitan pada aspek penyerapan, akuntabilitas, dan efisiensi, dan sudut pandang Activity-based Costing. Bagian akhir analisis, dibuat simpulan implementasi penganggaran berbasis kinerja dan improve penganggaran berbasis kinerja mendatang.

Implementasi

Berbasis Kinerja dari Aspek Penyerapan Anggaran

Penyerapan merupakan realisasi dari anggaran. Tohom (2015) 
Tabel 2. Tahapan dalam Penganggaran Berbasis Kinerja

\begin{tabular}{|c|c|c|}
\hline No. & Uraian Kegiatan & Dokumen \\
\hline 1. & $\begin{array}{l}\text { Penetapan visi } \\
\text { dan misi } K / L\end{array}$ & $\begin{array}{l}\text { Renstra K/L dan } \\
\text { tupoksi K/L }\end{array}$ \\
\hline 2. & $\begin{array}{l}\text { Perumusan } \\
\text { sasaran strategi } \\
\mathrm{K} / \mathrm{L}\end{array}$ & Renstra K/L \\
\hline 3. & $\begin{array}{l}\text { Restrukturisasi } \\
\text { program }\end{array}$ & Tupoksi Eselon 1 \\
\hline 4. & $\begin{array}{l}\text { Perumusan } \\
\text { outcome program }\end{array}$ & $\begin{array}{l}\text { Visi dan misi Eselon } \\
1\end{array}$ \\
\hline 5. & $\begin{array}{l}\text { Penetapan } \\
\text { Indikator Kinerja } \\
\text { Utama program }\end{array}$ & $\begin{array}{l}\text { IKU kegiatan } \\
\text { unggulan atau } \\
\text { pendekatan lain }\end{array}$ \\
\hline 6. & $\begin{array}{l}\text { Perumusan } \\
\text { kegiatan per } \\
\text { Eselon 2/Satker }\end{array}$ & $\begin{array}{l}\text { Tupoksi Eselon } \\
\text { 2/Satker }\end{array}$ \\
\hline 7. & $\begin{array}{l}\text { Penetapan output } \\
\text { kegiatan }\end{array}$ & $\begin{array}{l}\text { Output core } \\
\text { bussiness unit }\end{array}$ \\
\hline 8. & $\begin{array}{l}\text { Penetapan } \\
\text { Indikator Kinerja } \\
\text { Kegiatan }\end{array}$ & $\begin{array}{l}\text { Indikator Keluaran } \\
\text { Suboutput }\end{array}$ \\
\hline
\end{tabular}

Sumber: Kantor Pelayanan Kekayaan Negara dan Lelang (KPKNL) Palangkaraya (data diolah, 2020)

menyatakan bahwa aspek penyerapan anggaran merupakan salah satu indikator yang digunakan untuk mengukur kinerja output dan efisiensi dari tahapan perumusan, perencanaan, dan penganggaran pada mekanisme anggaran berbasis kinerja. Hal ini sejalan dengan penjelasan Lampiran PMK 142/PMK.02/2018 tentang Petunjuk Penyusunan dan Penelaahan Rencana Kerja dan Anggaran Kementerian Negara/Lembaga dan Pengesahan Daftar Isian Pelaksanaan Anggaran, bahwa agar penerapan penganggaran berbasis kinerja dapat dioperasionalkan, penganggaran berbasis kinerja menggunakan instrumen indikator kinerja, standar biaya, dan evaluasi kinerja. Salah satu evaluasi kinerja tersebut adalah penilaian terhadap realisasi penyerapan anggaran.

Sinaga (2016) mengatakan bahwa kegagalan target penyerapan anggaran akan berakibat pada hilangnya manfaat belanja. Sebab dana yang telah dialokasikan ternyata tidak sepenuhnya dapat dimanfaatkan dalam arti ada dana yang menganggur (idle). Apabila direncanakan dengan baik, dana yang menganggur tersebut seharusnya dapat digunakan untuk membiayai kegiatan strategis lainnya. Menurut penilaian Direktorat Jenderal Anggaran, dalam kerangka penganggaran berbasis kinerja, sebenarnya penyerapan anggaran bukan merupakan target capaian kinerja. Penganggaran berbasis kinerja lebih ditekankan pada kinerja daripada penyerapan itu sendiri. Namun, jika melihat kondisi perekonomian saat ini, variabel dominan pendorong pertumbuhan adalah faktor konsumsi. Belanja pemerintah merupakan konsumsi pemerintah sehingga penyerapan anggaran memiliki pengaruh yang besar terhadap perekonomian. Oleh karena itu, kebijakan penyerapan anggaran tidak terlepas dari siklus penganggaran dan evaluasi kinerja. Lebih lanjut, penyerapan anggaran dapat dipergunakan sebagai alat kendali dan strategi penerapan anggaran yang dapat mengarah pada peningkatan kinerja instansi pemerintah. Aspek penyerapan anggaran ini merupakan Indikator Kualitas Pelaksanaan Anggaran (IKPA).

Berdasarkan hasil penelitian Sofyani dan Prayudi (2018), semakin baik implementasi anggaran berbasis kinerja, penyerapan anggaran akan 
berjalan baik pula. Hal ini karena dalam penyusunan anggaran yang benarbenar direncanakan dengan berorientasi pada kinerja, tingkat penyerapan anggaran akan terjadwal secara rapi. Hal ini sesuai dengan pernyataan Bapak NS, operator anggaran KPKNL Palangkaraya, yang menyatakan bahwa di DJKN telah ditetapkan trajectory penyerapan anggaran IKU triwulanan sebagai acuan untuk memudahkan satuan kinerja dalam melakukan penyerapan anggaran. Tabel 3 menunjukkan target penyerapan anggaran.

Tabel 3. Target Penyerapan Anggaran

\begin{tabular}{|c|c|c|c|}
\hline \multicolumn{4}{|c|}{ Target Penyerapan anggaran atas pagu } \\
neto
\end{tabular}

Sumber: Kantor Pelayanan Kekayaan Negara dan Lelang (KPKNL) Palangkaraya (data diolah, 2020)

Adanya trajectory penyerapan anggaran memudahkan KPKNL untuk memantau, mengevaluasi, dan melaporkan informasi mengenai perkembangan belanja dan program yang sedang diselenggarakan. Hal ini disampaikan oleh Ibu HT, Kasubbag Umum yang menyatakan bahwa, "Trajectory diperlukan agar pelaksanaan pekerjaan atau kegiatan sesuai dengan rencana yang dibuat di awal tahun. Dengan demikian, KPKNL dapat mengantisipasi adanya penumpukan belanja dengan akselarasi tinggi di akhir tahun. Selain itu, Pejabat perbendaharaan dari mulai KPA, PPK, PPSPM dan bendahara pengeluaran dapat melakukan check dan re-check atas usulan dari masing-masing unit teknis yang terkait. Trajectory juga menjadi bahan bagi pemerintah khususnya Kementerian Keuangan dalam menyiapkan dana dalam rangka memenuhi kebutuhan $\mathrm{K} / \mathrm{L}$ untuk melaksanakan kegiatannya."

Pada setiap triwulan, KPKNL Palangkaraya menyampaikan laporan penganggaran yang berisi penggunaan anggaran dan capaian output yang diraih pada triwulan tersebut. Hal ini berguna untuk memastikan kesesuaian output yang direncanakan dengan realisasi belanja. Pada tahun 2019, capaian realisasi belanja KPKNL Palangkaraya mencapai 97,89\% melampaui target yang ditetapkan 95\%. Adapun rincian capaian penyerapan secara berturut-turut dari Triwulan I sampai dengan IV adalah 23,18\%; 58,3\%; 78,33\%; 97,89\%. Hasil tersebut mengindikasikan proses penyusunan perencanaan anggaran telah berorientasi pada kinerja sehingga pelaksanaanya melampaui target yang diharapkan.

\section{Implementasi \\ Berbasis Kinerja dari Aspek Akuntabilitas}

Hager, Habson, dan Wilson (2001) menyatakan bahwa penganggaran berbasis kinerja berbeda dengan mekanisme anggaran line item yang hanya berfokus pada akuntabilitas atas apa yang dibelanjakan pada sisi input. penganggaran berbasis kinerja lebih menekankan akuntabilitas atas apa yang telah dicapai organisasi dari pembelanjaan tersebut. Berdasarkan penjelasan Lampiran PMK 142/PMK.02/2018 tentang Petunjuk Penyusunan dan Penelaahan Rencana Kerja dan Anggaran Kementerian 
Negara/Lembaga dan Pengesahan Daftar Isian Pelaksanaan Anggaran, salah satu landasan konseptual yang mendasari penerapan penganggaran berbasis kinerja adalah terdapat fleksibilitas pengelolaan anggaran dengan tetap menjaga prinsip akuntabilitas (let the manager manages). Anggaran tidak hanya berfungsi sebagai alat perencanaan dan alat pengendalian, namun juga berfungsi sebagai instrumen akuntabilitas publik atas pengelolaan dana Anggaran Pendapatan dan Belanja Negara (APBN). Sebagai alat akuntabilitas publik, penggunaan anggaran harus dapat dipertanggungjawabkan dengan kinerja yang dicapai dari penggunaan dana APBN tersebut.

Hasil penelitian Sofyani dan Prayudi (2018) menyebutkan bahwa anggaran berbasis kinerja berpengaruh positif dengan akuntabilitas yang mengindikasikan bahwa semakin baik penerapan anggaran berbasis kinerja, semakin baik pula akuntabilitasnya, khususnya kinerja (Laporan Kinerja). Akuntabilitas kinerja diartikan sebagai perasaan bertanggung jawab untuk mencapai target capaian dari suatu program/kegiatan/kebijakan.

Akuntabilitas yang baik dicirikan dengan laporan yang disampaikan tepat waktu, serta serapan anggaran sesuai dengan target yang ditentukan. Selain itu, informasi kualitatif kinerja mudah dipahami dan memiliki relevansi untuk digunakan sebagai acuan perencanaan untuk anggaran periode berikutnya.

Terkait pelaporan, Bapak NS, operator anggaran KPKNL Palangkaraya, menyatakan bahwa KPKNL mengirimkan laporan penganggaran ke Kantor Pusat DJKN secara periodik triwulanan secara tepat waktu sesuai ketentuan setiap tanggal 5 pada bulan setelah berakhirnya triwulan. Laporan penganggaran tersebut berupa laporan IKU persentase kualitas pelaksanaan anggaran sebagai penerapan SE-2/MK.1/2019 tentang Tata Cara Penghitungan IKU Persentase Kualitas Pelaksanaan Anggaran di Lingkungan Kementerian Keuangan. Lebih lanjut, Bapak NS menyampaikan, "Input laporan tersebut terdiri dari data aplikasi Online Monitoring Sistem Perbendaharaan dan Anggaran Negara (OM SPAN) berupa data pagu dan realisasi anggaran beserta trajectory target penyerapan anggaran atas pagu neto, rencana penarikan dana dan realisasi bulanan, serta data bobot dan capaian IKPA. Selain itu KPKNL melakukan input data capaian keluaran dan capaian komponen, data capaian indikator output kegiatan, nilai capaian keluaran dan efisiensi sesuai aplikasi isian Sistem Monitoring dan Evaluasi Kinerja Terpadu Kementerian Keuangan (SMART) DJA".

Selain laporan persentase kualitas pelaksanaan anggaran triwulanan, laporan terkait penganggaran yang dilaporkan KPKNL antara lain Monev Bappenas berupa laporan hasil pemantauan pelaksanaan rencana pembangunan yang berisi ketercapaian realisasi anggaran dan fisik beserta status pelaksanaan setiap komponen. Laporan Monev Bappenas diisi setiap periode bulanan. Sementara itu, SMART DJA berisi capaian output dan persentase capaian setiap output.

Tahun 2019, ketepatan laporan KPKNL Palangkaraya mencapai target sebesar 100\%. Adapun realisasi penyerapan anggaran tahun 2019 
sebesar 97,89\% melewati target pelaksanaan sebesar 95\%. Informasi kualitatif kinerja anggaran yang dilaporkan mencakup sasaran strategis dan indikatornya, sasaran program dan indikatornya, serta sasaran kegiatan dan indikatornya. Informasi kinerja anggaran yang diperlukan untuk menyusun RKA-K/L adalah keluaran (output) program dan indikatornya, dan keluaran (output) kegiatan dan indikatornya. Selanjutnya realisasi capaian penganggaran tahun lalu akan digunakan sebagai acuan perencanaan anggaran periode berikutnya. Dengan demikian, dapat dikatakan bahwa akuntabilitas penganggaran KPKNL Palangkaraya tahun 2019 sudah baik jika dihubungkan dengan indikator hasil penelitian Sofyani dan Prayudi (2018) tersebut. Maka, KPKNL Palangkaraya sebagai pemegang amanah sesuai tugas dan fungsinya telah memberikan pertanggungjawaban dan informasi atas aktivitas dan kinerja anggaran pemerintah kepada pihak-pihak yang berkepentingan. Laporan Kinerja Tahunan secara rutin juga disampaikan melalui website resmi DJKN dengan alamat

URL

https://www.djkn.kemenkeu.go.id/kpknlpalangkaraya. Dengan demikian, publik bisa mendapat gambaran atas capaian kinerja yang telah diraih KPKNL termasuk hal penganggarannya.

\section{Implementasi \\ Penganggaran Berbasis Kinerja dari Aspek Efisiensi}

Kurniawan (2009) menyatakan bahwa penekanan terhadap efisiensi, efektivitas, dan ekonomis menjadi inti dari penganggaran berbasis kinerja. Salah satu instrumen penganggaran berbasis kinerja adalah evaluasi kinerja.
Cara pelaksanaan evaluasi terhadap masalah implementasi penganggaran berbasis kinerja dapat dilihat baik dari sisi efektivitas yaitu membandingkan hasil dengan target dan sisi efisiensi yaitu dengan membandingkan realisasi terhadap rencana pemanfaatan sumber daya. Penerapan penganggaran berbasis kinerja ditujukan salah satunya untuk meningkatkan efisiensi dan transparansi. Sejalan dengan hal itu, dalam berbagai kesempatan Menteri Keuangan memberi arahan kepada pengelola keuangan untuk melakukan efisiensi anggaran biaya pendukung, seperti biaya perjalanan dinas dan rapat-rapat di luar kantor.

Dalam konteks pengelolaan keuangan negara, efisiensi dapat dicapai antara lain adalah dengan menggunakan instrumen standar biaya. Adapun yang dimaksud dengan standar biaya itu sendiri adalah biaya setinggitingginya atau batas paling tinggi dari suatu barang dan jasa baik secara mandiri maupun gabungan yang diperlukan untuk memperoleh keluaran tertentu dalam rangka penyusunan anggaran berbasis kinerja (PMK Nomor 84/PMK.02/2005, PMK Nomor 96/PMK.02/2006, PMK Nomor 81/PMK.02/2007). Sebagai salah satu bentuk implementasi dari penganggaran yang efisien adalah dengan menerapkan standar biaya baik itu Standar Biaya Masukan (SBM) maupun Standar Biaya Keluaran (SBK) dalam perencanaan penganggaran. Lebih lanjut, sebagaimana dijelaskan pada Pasal 1 PMK Nomor 71 Tahun 2013 bahwa SBM adalah satuan biaya (tarif) yang ditetapkan untuk menyusun biaya komponen keluaran (output), sedangkan SBK adalah besaran biaya yang ditetapkan untuk menghasilkan 
keluaran (output)/sub keluaran (sub output) (Muliawan, 2017). Penyusunan penganggaran pada KPKNL Palangkaraya tahun 2019 telah sesuai dengan standar biaya yang berlaku yaitu PMK Nomor 32/PMK.02/2018 tentang Standar Biaya Masukan Tahun 2019.

Terkait pelaksanaan anggaran, Menteri Keuangan telah mengintruksikan gerakan efisiensi sebagai bahan implementasi penguatan budaya Kementerian Keuangan dengan menerbitkan Instruksi Menteri Keuangan (IMK) Nomor 346/IMK.01/2017. Efisiensi dapat dilakukan pada beberapa objek efisiensi IMK, antara lain perjalanan dinas, rapat dalam kantor, konsinyering/paket meeting, kudapan dan makan siang rapat, langganan daya dan jasa, honorarium tim dan narasumber, pengadaan barang dan jasa, belanja operasional perkantoran, belanja jasa, belanja pemeliharaan, dan belanja lainnya. Efisiensi biaya yang dilakukan oleh KPKNL Palangkaraya dapat dilihat pada Lampiran 1.

Dari hasil penghitungan efisiensi tersebut, capaian keluaran riil pada output 001 Layanan Pengelolaan Kekayaan Negara mencapai 314,85\%. Indikasi yang ada adalah apakah penentuan target keluaran riil pada output 001 tersebut terlalu rendah sehingga capaiannya 3 (tiga) kali lipat dari target. Hasil wawancara dengan Bapak GYF, pelaksana Seksi PKN menyatakan bahwa pada pada tahun 2019 Seksi Pengelolaan Kekayaan Negara (PKN) KPKNL Palangkaraya giat melakukan sosialisasi dan bersurat ke satker pengguna barang agar Penetapan Status Penggunaan (PSP) bisa mencapai $100 \%$. Hal ini sebagaimana arahan dari Kakanwil untuk menggenjot PSP. Maka, terjadi lonjakan permohonan status penggunaan, bahkan satker seperti Kanwil Kementerian Hukum dan HAM Kalimantan Tengah, mengajukannya. Hasilnya, 100\% barangnya (BMN) sudah ditetapkan status penggunaanya (PSP).

Di KPKNL sendiri, monitoring hasil efisiensi dilakukan setiap triwulan. Salah satunya melalui pengisian capaian efisiensi pada aplikasi SMART DJA. Menurut pernyataan Ibu MA, Bagian Penganggaran Kantor Pusat DJKN, bahwa Dikarenakan hasil capaian pada aplikasi SMART DJA berada pada rentang -20 sampai 20, maka dalam perhitungan IKU Kualitas Pelaksanaan Anggaraan sesuai SE-2/MK-1/2019, dilakukan konversi dengan menambahkan 90\%, sehingga nilai maksimal capaian $110 \%$.

Sementara itu, menurut Bapak NS, operator anggaran, "Hasil Capaian indikator IKU KPKNL Palangka Raya pada capaian efisiensi adalah 104,9\% yang merupakan hasil capaian efisiensi menurut SMART DJA sebesar 14,93\% ditambahkan 90\% untuk konversi ke Capaian IKU. Dengan demikian, KPKNL Palangkaraya telah melakukan efisiensi melebihi target $100 \%$ (capaian 104,9\%)." Manfaat lain dari monitoring efisiensi ini adalah ketika ada indikasi kelebihan dana pada pos tertentu, dana dapat dialihkan untuk pos (akun) lain yang lebih memerlukan untuk mengoptimalkan capaian kinerja satker.

Terkait hal penyusunan dan pelaksanaan anggaran di sektor publik yang berorientasi pada pemberian pelayanan, maka hal utama adalah memperhatikan kualitas kemudian baru efisiensi. Hal demikian disampaikan oleh Bapak SG, Kepala KPKNL 
Palangkaraya, "Efisiensi anggaran sangat penting, namun jangan sampai melupakan kualitas. Misalnya membangun gedung, kalau hanya memikirkan efisiensi, barangkali ke depan biaya pemeliharaannya nanti justeru melebihi efisiensinya. Niat mau berhemat malah justeru boros. Oleh karena itu, selain ketika menyusun berdasarkan patokan harga SBM dan pelaksanaannya dalam tahun berjalan, efisiensi sebetulnya bisa dilakukan kalau bisa menawar harga barang lebih rendah dari budget. Kalau sampai kurang, tidak akan terbeli, sementara itu proses rivisi belum tentu mudah mengingat ada batasan kewenangannya".

\section{Implementasi \\ Penganggaran Berbasis Kinerja Dikaitkan dengan Pendekatan ABC}

Hansen dan Mowen (2007)

menjelaskan bahwa Activity-based Costing $(A B C)$ adalah suatu sistem akuntansi yang berfokus pada aktivitasaktivitas yang dilakukan untuk menghasilkan produk/jasa. Dalam sistem $A B C$, biaya ditelusuri ke aktivitas dan kemudian ke produk. Sistem mengasumsikan sumber daya dan bukannya produk. Activity-based Costing berguna dalam penetapan biaya anggaran, kewajaran anggaran belanja, dan pengelolaannya lebih lanjut (Activity-based Management) akan mampu mencegah pemborosan anggaran.

Dalam pemerintahan, pendekatan $A B C$ dalam sistem penganggaran masih terkendala dengan output beragam. Sebagai contoh, KPKNL Palangkaraya memiliki tusi yang bervariasi mulai dari pengelolaan kekayaan negara, pengurusan piutang negara, pelayanan lelang, hingga pelayanan penilaian. Jika dirinci, penghitungan biaya pelayanan berdasarkan detail kegiatan yang dilakukan tentu akan sangat kompleks.

Menurut Hansen dan Mowen (2007), anggaran berbasis aktivitas dapat dibedakan menjadi dua yaitu anggaran statis dan anggaran fleksibel. Dalam anggaran statis, aktivitas menimbulkan biaya dengan mengonsumsi sumber daya yang jumlahnya bergantung pada output aktivitas. Tiga langkah anggaran berbasis aktivitas antara lain aktivitas dalam organisasi harus diidentifikasi, kemudian permintaan tiap output aktivitas harus diperkirakan, dan biaya sumber daya yang diperlukan untuk memproduksi tingkat aktivitas yang ingin dicapai harus dinilai. Berdasarkan pada pandangan Hansen dan Mowen ini, KPKNL Palangkaraya dapat dikatakan telah mengimplementasikan sistem Activity-based Costing atau Activity-based Management yaitu dengan melaksanakan ketiga langkah tersebut yakni identifikasi aktivitas, output ditentukan, dan biaya sumber daya disediakan. Dengan demikian, Activity-based Costing KPKNL mendorong sistem penganggaran berbasis kinerja lebih terarah (menekankan kinerja penganggaran). Studi Vakilifard, Zeynali, dan Mohammadipour (2010) menguatkan hal ini, bahwa implementasi penganggaran berbasis kinerja dikaitkan dengan analisis $A B C$ akan mempermudah pencapaian tujuan penganggaran berbasis kinerja (efisiensi, efektivitas, ekonomi, dan orientasi keluaran dan hasil).

Terkait langkah mengidentifikasi aktivitas dalam organisasi, KPKNL secara periodik sesuai jadwal 
penyusunan anggaran yaitu sebelum penyusunan pagu indikatif melaksanakan resource forum. Forum manajerial ini dihadiri oleh Kepala Kantor selaku Kuasa Pengguna Anggaran (KPA), Pejabat Pembuat Komitmen (PPK), Pejabat Penandatangan Surat Perintah Membayar (PPSPM), Bendahara, dan para Kepala Seksi sebagai sarana untuk mengharmonisasikan alokasi anggaran dengan kebutuhan riil dan roadmap organisasi.

Langkah kedua yaitu memperkirakan output aktivitas, KPKNL dalam hal ini secara konsisten setiap penyusunan anggaran memperkirakan target volume output yang akan dicapai dengan mempertimbangkan pada capaian riil tahun sebelumnya. Proses penentuan volume output dapat dilihat pada Gambar 1 di bawah ini.

Target volume output ini kemudian dituangkan pada Kerangka Acuan Kerja (KAK)/term of reference (TOR). KAK memberikan gambaran umum dan penjelasan mengenai output yang akan dicapai sesuai dengan tugas dan fungsi unit Eselon 1 dalam hal ini adalah DJKN, yang memuat latar belakang output, penerima manfaat output, strategi pencapaian output, kurun waktu pencapaian aktivitas output, dan biaya yang diperlukan.

Dokumen perencanaan kegiatan ini menjelaskan mengenai apa (what), mengapa (why), siapa (who), kapan (when), dimana (where), bagaimana (how), dan berapa perkiraan biayanya suatu kegiatan/output.

Gambar 1. Penghitungan Volume Komponen dan Output

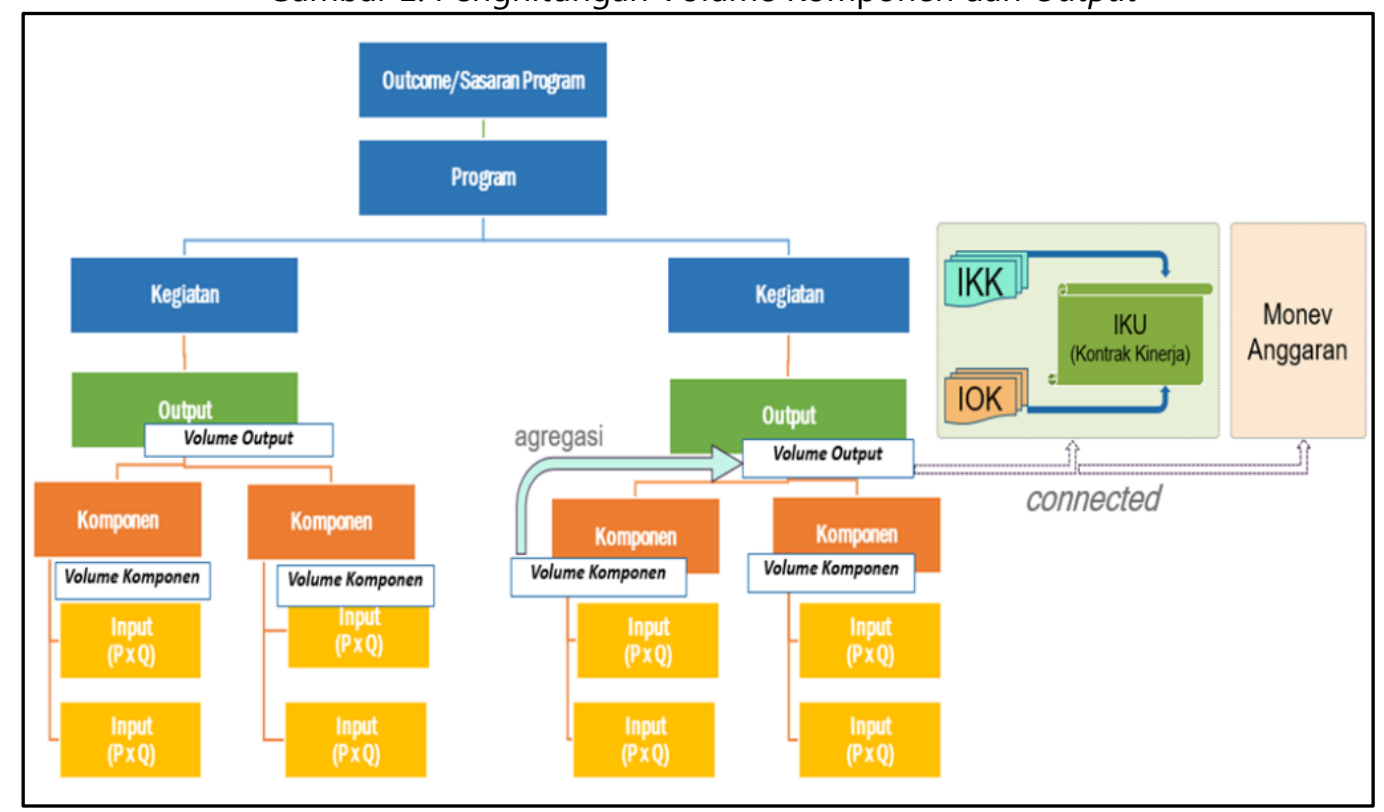

Sumber: Keterkaitan Kegiatan dan Output Palangkaraya, 2019 
Dalam menentukan biaya yang diperlukan yang merupakan langkah ketiga, KPKNL membuat Rincian Anggaran Biaya (RAB) tiap output sesuai harga satuan dalam Standar Biaya Masukan (SBM) yang berlaku. RAB adalah suatu dokumen yang berisi tahapan pelaksanaan, rincian komponen-komponen masukan dan besaran biaya dari setiap komponen suatu kegiatan.

Sementara itu, anggaran fleksibel merupakan anggaran prediksi biaya aktivitas dan memungkinkan jika terjadi perubahan dalam output aktivitas. Analisis variansi dalam suatu kerangka kerja aktivitas memungkinkan perbaikan dalam pelaporan kinerja anggaran tradisional. Hal ini juga meningkatkan kemampuan untuk mengelola aktivitas. Bila melihat pada instansi pemerintah, terdapat mekanisme revisi anggaran.

Tata cara revisi anggaran ditetapkan tiap tahun disesuaikan dengan amanat UU APBN, arahan pimpinan dan masukan dari unit-unit terkait, serta disempurnakan dengan kebijakan penganggaraan terkini. Akan tetapi revisi anggaran berdasarkan
Peraturan Menteri Keuangan Nomor 206/PMK.02/2018 tentang Tata Cara Revisi Anggaran TA 2019 menyatakan bahwa revisi anggaran dapat dilakukan sepanjang tidak mengubah sasaran kegiatan, jenis dan satuan keluaran (output), dan tidak mengubah (output) yang sudah direalisasikan. Terkait penyelesaian revisi anggaran ada yang berada pada kewenangan Direktorat Jenderal Anggaran, Direktorat Jenderal Perbendaharaan, Kuasa Pengguna Anggaran, bahkan sampai memerlukan persetujuan Dewan Perwakilan Rakyat (DPR).

KPKNL Palangkaraya selama ini telah melakukan revisi anggaran hanya sampai pada Kuasa Pengguna Anggaran dan Kanwil Direktorat Jenderal Perbendaharaan. Tahun Anggaran 2019, KPKNL Palangkaraya telah melakukan revisi pergeseran anggaran dari satu ouput ke output lain sebanyak 6 (enam) kali. Dengan demikian, dapat dikatakan bahwa anggaran KPKNL Palangkaraya memungkinkan fleksibilitas dalam hal revisi anggaran terbatas sesuai ketentuan PMK revisi anggaran yang berlaku.

Gambar 2. Monitoring Revisi Anggaran KPKNL Palangkaraya Tahun 2019

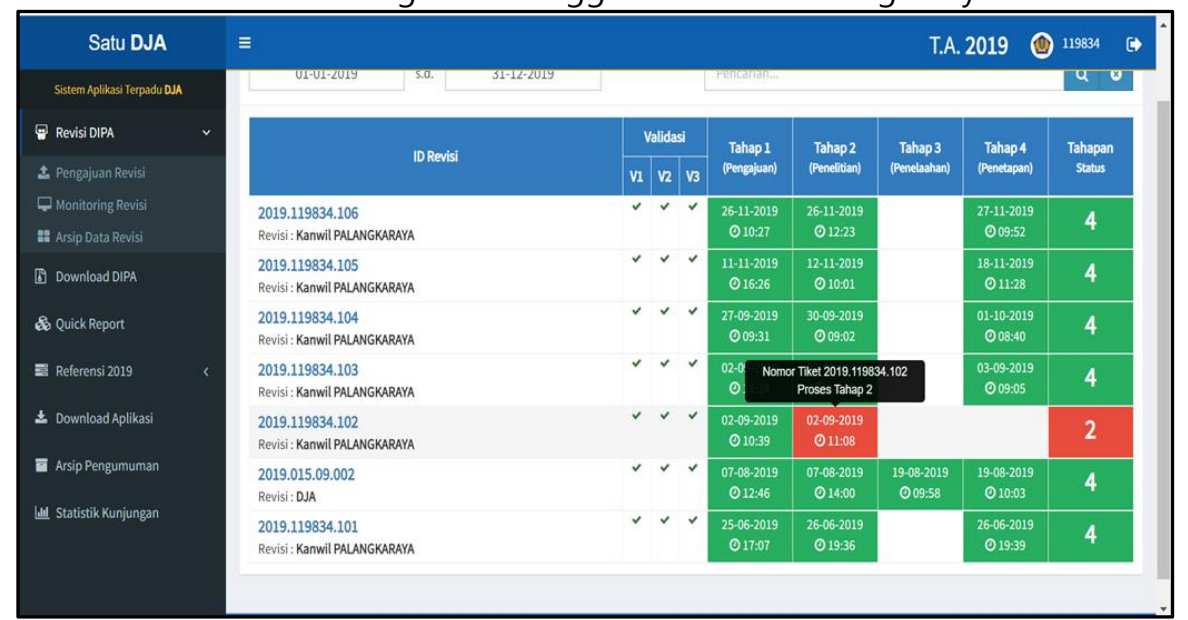

Sumber: Pelaporan Revisi Anaaaran KPKNL Palanakarava. 2019 
Revisi yang dilakukan KPKNL Palangkaraya termasuk dalam revisi adminitratif. Hal ini sesuai dengan pernyataan Bapak NS bahwa, "Pada Tahun 2019, revisi yang kita lakukan bukan revisi anggaran yang menyebabkan penambahan atau pengurangan pagu, sehingga revisi dalam kewenangan pagu sifatnya tetap dan revisi administratif ini tidak diperhitungkan masuk IKPA". Dengan demikian, nilai IKPA untuk revisi DIPA satker KPKNL Palangkaraya tahun 2019 adalah $100 \%$.

\section{Kelemahan \\ Implementasi \\ Penganggaran Berbasis Kinerja di Lapangan dan Upaya Perbaikan}

Dalam penyusunan anggaran, DJKN telah menerapkan Arsitektur dan Informasi Kinerja (ADIK). Hal ini sesuai dengan pernyataan Ibu MA, bagian penganggaran Kantor Pusat DJKN, yang menyatakan, "Penyusunan anggaran kita sudah menggunakan ADIK yang terefleksi pada struktur dan informasi kinerja dalam penganggaran. ADIK tersebut didesain dengan menerima masukan dari semua elemen baik dari Kantor Pusat (Direktorat Teknis) maupun instansi vertikal". Dengan demikian, terdapat keseragaman antar KPKNL maupun antar Kanwil di Direktorat Jenderal Kekayaan Negara. Studi Fitrianty dan Biswan (2018) menyatakan bahwa praktik sistem penganggaran melalui ADIK yang merupakan strategi penyempurnaan dari penganggaran berbasis kinerja dapat mempertajam informasi mengenai keterkaitan antara fungsifungsi suatu organisasi dengan organisasi di atasnya sehingga dapat dengan mudah ditelusuri dan dipahami keterkaitan informasi-informasi seperti kondisi apa yang ingin dicapai, produk apa yang bisa memenuhi kondisi tersebut, bagaimana cara menghasilkan produk, dan sumber daya apa yang dimiliki untuk melakukan kegiatan tersebut.

Hal yang menarik dari studi penganggaran berbasis kinerja di KPKNL berdasarkan penggalian data, wawancara dengan Ibu HT, Bapak NS, dan Ibu MA, dan penilikan kondisi riil, ditemui beberapa kelemahan implementasi penganggaran berbasis kinerja baik langsung maupun tidak langsung. Kekhawatiran tidak selaras antara perencanaan dan program juga disinggung pada studi Hartanto, Busaini, Animah (2018). Hal ini bukan hal mengkhawatirkan jika ditangani dengan baik. Menurut hemat peneliti, kendala implementasi juga dijumpai pada banyak studi penganggaran berbasis kinerja, mengingat terdapat perubahan paradigma penganggaran dari sistem tradisional ke penganggaran berbasis kinerja. Yang pertama adalah pola pikir bahwa anggaran dari tahun ke tahun harus bertambah dan perilaku yang mendewakan anggaran: kalau tidak ada anggaran, tidak jadi melaksanakan kegiatan tertentu. Dalam sistem penganggaran berbasis kinerja, ada design untuk melakukan revisi anggaran. Hal ini mengisyaratkan seharusnya instansi tidak perlu khawatir jika ada kekurangan anggaran. Juga pada kondisi output dan outcome sama, anggaran dari tahun ke tahun tidak harus selalu bertambah.

Pada penyusunan anggaran, setiap instansi berlomba-lomba mengajukan anggaran yang besar, meskipun kemudian ditelaah Kantor Pusat dan selalu terjadi pemotongan dari yang 
diajukan. Tak jarang untuk menghindari kerumitan dalam proses revisi (selain revisi Kuasa Pengguna Anggaran dan Kanwil Direktorat Jenderal Perbendaharaan), Satker mengurungkan revisi jika memang tidak terlalu urgen. Oleh karena itu, penting sekali mendorong pemahaman terkait penganggaran berbasis kinerja khususnya pada penyusun/PIC anggaran maupun Pimpinan Satker. Proses sosialisasi akan memperkecil gap perencanaan anggaran dan eksekusinya (Dahana \& Ermawati, 2020). Hal ini karena pada dasarnya penganggaran berbasis kinerja memudahkan Satker dalam merencanakan dan melaksanakan anggaran dengan efektif dan efisien, bukannya membatasi kegiatan. PIC penganggaran yang andal akan mengupayakan anggaran sekalipun dengan kegiatan yang benar-benar baru. Tentunya output yang benarbenar masih baru tidak diajukan pada tahun berjalan namun untuk perencanaan tahun selanjutnya.

Selain itu selama ini, output masih dimaknai sebagai dokumen administrasi. Output merupakan barang atau jasa yang dihasilkan oleh kegiatan yang dilaksanakan untuk mendukung pencapaian sasaran dan tujuan program dan kegiatan. Indikator output yang akan dicapai dalam penganggaran berbasis kinerja dijadikan pertimbangan dalam penyusunan anggaran. Dengan demikian, indikator output sebenarnya sangat berperan dalam menentukan kualitas belanja. Output yang baik akan memberikan outcome (hasil) yang baik, kemudian benefit yang baik diharapkan dapat dicapai. Hal ini selaras dengan studi Marsus dan Mas'udin (2020) yang menyimpulkan bahwa implementasi penganggaran berbasis kinerja memberikan dampak efektivitas program K/L dan mengurangi duplikasi aktivitas $K / L$, meskipun salah satu problem penganggaran berbasis kinerja terberat adalah formulasi ukuran kinerja.

Berangkat dari kelemahan implementasi penganggaran berbasis kinerja yang jamak dijumpai di instansi pemerintahan, penting diadakan penajaman pemahaman atas pendefinisian output agar lebih mencerminkan kegiatan bukan sekedar dipandang pada dokumen administrasi saja. Studi Mohammadipour (2014) menyebutkan bahwa kendala implementasi penganggaran berbasis kinerja dikaitkan dengan minimnya kesadaran atas sumber daya, minimnya familiarity dengan sistem penganggaran berbasis kinerja yang otomatis keduanya menjadi penghalang sukses penganggaran berbasis kinerja. Sistem penganggaran berbasis kinerja menuntut para pelaku penganggaran untuk memahami betul setiap aktivitas, input, output, bahkan outcome yang akan dicapai jika menginginkan hasil yang optimal.

Studi Friyani dan Hernando (2019) menekankan bahwa pelatihan, pemahaman, edukasi, dan tekanan luar memberikan efek positif atas implementasi penganggaran berbasis kinerja dan penyerapan anggaran. Secara lebih luas, Dipayana, Triyuwono, dan Andayani (2017) merinci permasalahan penganggaran berbasis kinerja yakni perbedaan dokumen perencanaan dan penganggaran, pelaporan kinerja belum sepenuhnya mulus, sumber daya manusia yang memerlukan penguatan, dan sistem terintegrasi masih belum optimal. 


\section{KESIMPULAN DAN SARAN}

Simpulan didasarkan atas analisis data dan fakta penganggaran, lalu sintesis peneliti dengan menyarikan penguatan-penguatan fakta dari para narasumber. Berdasarkan analisis di atas, penganggaran berbasis kinerja telah banyak memberikan dampak positif pada pelaksanaan anggaran KPKNL Palangkaraya. Permasalahan inkonsistensi perencanaan dan eksekusi pelaksanaan anggaran seperti studi Savignon, Costumato, dan Marchese (2019) dapat diatasi dengan manajemen anggaran yang baik. Dalam aspek penyerapan anggaran, KPKNL Palangkaraya telah menerapkan trajectory penyerapan anggaran agar dapat mengantisipasi adanya kemungkinan terjadinya penumpukan belanja di akhir tahun. Dengan adanya trajectory ini, penyerapan anggaran pada tahun 2019 mampu melampaui target yang ditetapkan dengan rincian yang merata tiap triwulannya. Penyerapan anggaran yang baik berkontribusi pada meningkatnya kinerja KPKNL Palangkaraya dikarenakan penyerapan anggaran merupakan salah satu indikator yang diukur dalam melaksanakan evaluasi kinerja. Terkait aspek akuntabilitas, KPKNL Palangkaraya telah melaksanakan pertanggungjawaban pelaksanaan anggaran melalui pelaporan secara tepat waktu kepada Kantor Pusat DJKN dan publikasi atas informasi aktivitas dan kinerja anggaran pada laman resmi DJKN.

Selanjutnya dalam aspek efisiensi, yaitu aspek yang mengevaluasi kinerja dengan membandingkan realisasi dan rencana penggunaan sumber daya yang tersedia. KPKNL Palangkaraya telah melaksanakan monitoring hasil efisiensi tiap triwulan. Hal ini dilakukan agar jika ada kelebihan anggaran untuk pencapaian suatu output, maka KPKNL Palangkaraya dapat mengalokasikan kelebihan anggaran tersebut pada pencapaian output lain yang kiranya lebih memerlukan tambahan anggaran. Selain itu, pemindahan anggaran ini juga dilakukan dalam rangka menjaga kualitas pelayanan yang diberikan oleh KPKNL Palangkaraya sehingga yang menjadi fokus adalah pencapaian seluruh output kemudian penyerapan anggaran.

Analisis selanjutnya terkait dengan penerapan Activity-based Costing pada KPKNL Palangkaraya. Dalam proses penganggarannya, KPKNL Palangkaraya sudah menerapakan prinsip-prinsip Activity-based Costing yang dapat dilihat melalui penyelenggaraan resource forum untuk mengharmonisasikan alokasi anggaran dengan kebutuhan riil dan roadmap organisasi, serta penyusunan Kerangka Acuan Kerja (KAK) dan Rincian Anggaran Biaya (RAB) yang menggambarkan hubungan output yang akan dicapai dengan tugas dan fungsi organisasi. Selain itu, KPKNL Palangkaraya juga telah menerapkan flexible budget sebagaimana dijelaskan melalui analisis sebelumnya terkait aspek efisiensi. Selama tahun 2019, KPKNL Palangkaraya telah melakukan pergeseran anggaran terhitung sebanyak 6 (enam) kali yang menggambarkan bahwa KPKNL Palangkaraya menggunakan prinsip flexible budget dalam rangka pencapaian output-nya meskipun terdapat kendala berupa jenis output yang sangat bervariasi sehingga 
menyulitkan perhitungan biaya pelayanan berdasar rincian kegiatan.

Terkait kendala implementasi, institusi dapat mengintensifkan diskusi dan sharing session pemahaman penganggaran berbasis kinerja tidak hanya internal, terlebih kepada penyusun anggaran/PIC penyusun maupun Pimpinan Satker sebagai mitra. Keselarasan pemahaman penganggaran berbasis kinerja akan memperbaiki perencanaan dan penganggaran berikutnya, sehingga pola pikir lama bahwa penganggaran harus bertambah dari tahun ke tahun, perilaku mendewakan anggaran, anggaran tidak bisa diubah, serta output kegiatan harus administratif dan harus ada sebelumnya, dapat diminimalisasi.

\section{IMPLIKASI DAN}

\section{KETERBATASAN}

Analisis eksploratif dalam studi ini dipengaruhi persepsi peneliti yang salah satunya merupakan pegawai di kantor objek. Peneliti yang terlibat dalam studi kualitatif yang merupakan bagian dari objek yang diteliti disadari memberikan dua persepsi yakni pro dan kontra. Dikatakan pro karena peneliti memiliki keterlibatan langsung sehingga memahami persoalan dengan sangat baik. Solusi yang diberikan pun lebih riil mendekati apa yang terjadi. Hal ini lazim terjadi pada studi kualitatif seperti penelitian ini. Dikatakan kontra karena unsur subjektivitas. Untuk mengurangi subjektivitas, penelitian ini melibatkan tim pengolah data yang bukan berasal dari instansi objek yang diteliti sehingga menggunakan perspektif yang lebih komprehensif.

Penggunaan satu kasus yang digunakan dalam penelitian belum memperlihatkan hasil yang lebih komprehensif terkait kondisi yang terjadi pada sektor publik di Indonesia. Hasil penelitian ini juga dapat dijadikan gambaran baik bagi kantor pemerintahan terkait dengan penerapan penganggaran berbasis kinerja. Oleh karena itu, penelitian selanjutnya dapat menggunakan beberapa objek organisasi sektor publik untuk mendapatkan hasil yang lebih bervariasi untuk dapat membandingkan dengan hasil penelitian ini.

Jika jumlah objek studi lebih banyak, penelitian penganggaran berbasis kinerja juga bisa menggunakan pendekatan bauran antara kuantitatif dan kualitatif sehingga memberi gambaran lebih utuh. Umumnya studi kuantitatif melibatkan beberapa periode sehingga tren implementasi terekam dengan lebih baik.

\section{REFERENSI}

Badan Perencanaan dan Pembangunan Nasional. (2009). Pedoman Penerapan Anggaran Berbasis Kinerja. Jakarta.

Dahana, M. A. \& Ermawati. (2020). Analysis of The Budget Planning Process and Budget Execution Process. EJBMR European Journal of Business and Management Research. Vol. 5, No. 4, July 2020. DOI: http://dx.doi.org/10.24018/ejbmr.2 020.5.4.426.

Dipayana, M.A., Triyuwono, I., \& Andayani W. (2017). The Process of Performance Based Budgeting in Probolinggo City by Utilizing Simral: A Phenomenology Study. Journal of Accounting and Business 
Education.

DOI:

http://dx.doi.org/10.26675/jabe.v1i 1.9753.

Fadilah, S. (2009). Activity Based Costing $(A B C)$ sebagai Pendekatan Baru untuk Menghitung Analisis Standar Belanja (ASB) dalam Penyusunan Anggaran Pendapatan Belanja Daerah. Jurnal Telaah \& Riset Akuntansi. Vol. 2. No. 1 Januari 2009 Hal. 54-78.

Fitrianty, D., \& Biswan, A.T. (2018). Praktik Sistem Penganggaran Melalui Penataan Arsitektur dan Informasi Kinerja. Jurnal Manajemen Keuangan Publik, 2 (1), 34-46. Retrieved from http://jurnal.pknstan.ac.id/index.ph p/JMKP/article/view/JMKP183.

Friyani, R \& Hernando, R. (2019). Determinants of The Effectiveness Of Implementation Performance Based-Budgeting and Budget Absorption in Local Government (Study on Jambi City Government). Sriwijaya International Journal of Dynamic Economics and Business 3(3):213. DOI: 10.29259/sijdeb.v3i3.213-226

Hager, G., Hobson, A, \& Wilson, G. (2001).

Performance-Based Budgeting: Concepts and Examples. Frankfort. Kentucky: Committee for Program Review and Investigations.

Hansen, D.R. \& Mowen, M.M. (2007). Managerial Accounting. Edisi ke-8. China: South-Western Cengage Learning.

Hartanto, M.R., Busaini, \& Animah. (2018). Implementation of Performance-Based Budgeting: A Phenomenological Study on National Land Agency. International Journal of Scientific
Research and Management (IJSRM). Vol. 06 Issue 03 Hal. 122-131. DOI: 10.18535/ijsrm/v6i2.em06

Kementerian Keuangan \& Kementerian Negara Perencanaan Pembangunan Nasional. (2009). Pedoman Penerapan Penganggaran Berbasis Kinerja. Buku 2. Jakarta.

Kementerian Keuangan Republik Indonesia (2019). Konsep Perencanaan Penganggaran. Diklat Perencanaan dan Penganggaran Kementerian Keuangan. Jakarta

Krispahanripi, P.D. (2017). Pengaruh Perapan Anggaran Berbasis Kinerja dan Anggaran Berbasis Kinerja terhadap Akuntabilitas Kinerja Instansi Pemerintah (Studi Kasus pada Badan Pengelolaan Keuangan dan Aset Kota Bandung). (Diploma thesis). Universitas Komputer Indonesia.

Kurniawan. (2009). Pengaruh Penganggaran Berbasis Kinerja terhadap Akuntabilitas Kinerja Instansi Pemerintah Daerah di Wilayah IV Priangan. (Skripsi). UPI. Jakarta.

Mardiasmo. (2009). Akuntansi Sektor Publik. Yogyakarta: ANDI.

Marsus, S. \& Mas'udin. (2020). Does the Performance-Based Budgeting Work in Indonesia?. International Journal of Scientific \& Technology Research. Vo. 9, Issue 02, February 2020.

Mohammadipour, R. (2014). A Study on the Effect of Performance Based Budgeting Using Activity-Based Cost Method. Management Science Letters 4 (2014) 145-148. doi: 10.5267/j.msl.2013.11.021.

Muliawan, Y. (2017). Analisis Kebutuhan Pengaturan Billing Rate oleh 
Menteri Keuangan. Jurnal Sistem Penganggaran Sektor Publik. Volume 1. DJA.

Peraturan Menteri Keuangan Nomor 142/PMK.02/2018 Petunjuk Penyusunan dan Penelaahan Rencana Kerja dan Anggaran Kementerian Negara/Lembaga dan Pengesahan Daftar Isian Pelaksanaan Anggaran. Retrieved from

http://www.anggaran.kemenkeu.g o.id/peraturan/2018\%20PMK\%201 42\%202018.pdf.

Peraturan Menteri Keuangan Nomor 206/PMK.02/2018 Tata Cara Revisi Anggaran Tahun Anggaran 2019. Retrieved from http://www.anggaran.kemenkeu.g o.id/peraturan/2018\%20PMK\%202 06\%202018.pdf.

Savignon, A. B., Costumato, L. \& Marchese, M. (2019). Performance Budgeting in Context: An Analysis of Italian Central Administrations. MPDI Journal. Adm. Sci. 2019, 9, 79. DOI:10.3390/admsci9040079.

Shah, A. (2007). Budgeting And Budgetary Institutions. The International Bank for Reconstruction and Development: The World Bank.

Sinaga, E.S. (2016). Analisis Rendahnya Penyerapan Anggaran Kementerian/Lembaga (K/L) dan Pemerintah Daerah. Jurnal Rechts Vinding. 5 (2), 264-274. Retrieved from https://rechtsvinding.bphn.go.id/ar tikel/ART\%208\%20JRV\%205.2\%20 WATERMARK.pdf.

Sofyani, H., \& Prayudi, M.A. (2018). Implementasi Anggaran Berbasis Kinerja di Pemerintah Daerah dengan Akuntabilitas Kinerja "A".
Jurnal Ilmiah Akutansi dan Bisnis, 13 (1), 54-64. Retrieved from https://doi.org/10.24843/JIAB.2018 .v13.i01.p06.

Surianti, M. \& Dalimunthe, A.R. (2015). The Implementation of Performance Based Budgeting in Public Sector (Indonesia Case: A Literature Review). Research Journal of Finance and Accounting. Vol. 6, No. 12.

Tohom, A. (2015). Penyerapan Anggaran=Kinerja Anggaran?. Warta Pengawasan XXII, 2-9.

Vakilifard, H., Zeynali, M., \& Mohammadipour, R. (2010). The Relation Between PerformanceBased Budgeting and ActivityBased Budgeting. American Journal of Finance and Accounting 2(1):6574. DOI: 10.1504/AJFA.2010.034568. 


\section{Lampiran}

Lampiran 1. Hasil Efisiensi Tahun 2019

\begin{tabular}{|c|c|c|c|c|c|c|c|}
\hline \multirow[b]{2}{*}{ No } & \multirow{2}{*}{\multicolumn{2}{|c|}{ OUTPUT/OBJEK EFISIENSI }} & \multirow[b]{2}{*}{ AKUN } & \multicolumn{4}{|c|}{ TRIWULAN IV } \\
\hline & & & & \begin{tabular}{c|}
$\%$ \\
CAPAIAN \\
KELUARA \\
N RIIL
\end{tabular} & PAGU AKHIR (Rp) & $\begin{array}{l}\text { REALISASI S.D. } \\
\text { TRIWULAN IV } \\
\text { (Rp) }\end{array}$ & $\begin{array}{c}\text { HASIL EFISIENSI } \\
\text { (Rp) }\end{array}$ \\
\hline (1) & & (2) & & (15) & (16) & (17) & (18) \\
\hline \multirow[t]{7}{*}{1} & \multicolumn{3}{|c|}{ Layanan Pengelolaan Kekayaan Negara sesuaiKewenangan KPKNL } & $314,85 \%$ & 225.423.000 & 213.408 .000 & 12.015 .000 \\
\hline & & Perjalanan Dinas & 524111,524113 & & 146.890 .000 & 142.508 .200 & 4.381 .800 \\
\hline & & Konsinyering/Paket Meeting & 524114,524119 & & - & - & - \\
\hline & & Kudapan dan Makan Siang Rapat & 521211 & & 35.918 .000 & 31.218 .000 & 4.700 .000 \\
\hline & d. & Honorarium Tim dan Narasumber & 521213,522151 & & - & - & \\
\hline & e. & Pengadaan Barang dan Jasa & 521811 & & 42.615 .000 & 39.681 .800 & 2.933 .200 \\
\hline & f. & Belanja Lainnya & 521219,522141 & & & & \\
\hline \multirow[t]{7}{*}{2} & \multicolumn{3}{|c|}{ Layanan Pengurusan Piutang Negara sesuai Kewenangan KPKNL } & \multirow[t]{2}{*}{$180,00 \%$} & 73.587 .000 & 68.815.206 & 4.771 .794 \\
\hline & & Perjalanan Dinas & 524111,524113 & & 18.754 .000 & 16.626 .372 & 2.127 .628 \\
\hline & & Konsinyering/Paket Meeting & 524114,524119 & & - & - & \\
\hline & c. & Kudapan dan Makan Siang Rapat & 521211 & & 2.731 .000 & 2.725 .000 & 6.000 \\
\hline & d. & Honorarium Tim dan Narasumber & 521213,522151 & & 28.500 .000 & 27.000 .000 & 1.500 .000 \\
\hline & e. & Pengadaan Barang dan Jasa & 521811 & & 23.602 .000 & 22.463 .834 & 1.138 .166 \\
\hline & f. & Belanja Lainnya & 521219,522141 & & & & \\
\hline \multirow[t]{7}{*}{3} & \multicolumn{3}{|c|}{ Layanan Lelang sesuai Kewenangan KPKNL } & $\mid 106,67 \%$ & 78.713 .000 & 77.232 .820 & 1.480 .180 \\
\hline & a. & Perjalanan Dinas & 524111,524113 & & 52.775 .000 & 51.491 .020 & 1.283 .980 \\
\hline & b. & Konsinyering/Paket Meeting & 524114,524119 & & & - & \\
\hline & c. & Kudapan dan Makan Siang Rapat & 521211 & & 5.050 .000 & 4.855 .000 & 195.000 \\
\hline & d. & Honorarium Tim dan Narasumber & 521213,522151 & & & 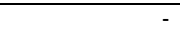 & \\
\hline & e. & Pengadaan Barang dan Jasa & 521811 & & 20.888 .000 & 20.886 .800 & 1.200 \\
\hline & f. & Belanja Lainnya & 521219,522141 & & & & \\
\hline \multirow[t]{7}{*}{4} & \multicolumn{2}{|r|}{ Layanan Sarana dan Prasarana Internal } & & \multirow[t]{2}{*}{$100,00 \%$} & 93.667.000 & 90.892.350 & 2.774 .650 \\
\hline & & Pengadaan Barang dan Jasa & 532111,532121 & & 64.398 .000 & 64.063 .300 & 334.700 \\
\hline & b. & Perjalanan Dinas & 524111,524113 & & 19.201 .000 & 18.270 .200 & 930.800 \\
\hline & c. & Konsinyering/Paket Meeting & 524114,524119 & & - & - & - \\
\hline & d. & Kudapan dan Makan Siang Rapat & 521211 & & - & - & \\
\hline & e. & Pengadaan Barang dan Jasa & 521811 & & 8.848 .000 & 8.558 .850 & 289.150 \\
\hline & f. & Belanja Lainnya & 521219,522151 & & 1.220 .000 & & 1.220 .000 \\
\hline \multirow[t]{5}{*}{5} & \multicolumn{2}{|c|}{ Layanan Perkantoran } & & $100,00 \%$ & 1.195 .884 .000 & 1.188.140.679 & 7.743 .321 \\
\hline & & Perjalanan Dinas & 524111,524113 & & 132.895 .000 & 130.982 .552 & 1.912 .448 \\
\hline & b. & Konsinyering/Paket Meeting & 524114,524119 & & & & \\
\hline & c. & Kudapan dan Makan Siang Rapat & 521211 & & 20.534 .000 & 20.511 .000 & 23.000 \\
\hline & d. & Langganan Daya dan Jasa & $\begin{array}{c}\text { Seluruh Akun pada Subkomponen } \\
\text { Langganan Daya dan Jasa }\end{array}$ & & 156.571 .000 & 155.632 .853 & 938.147 \\
\hline & e. & Honorarium Tim dan Narasumber & 522151 & & & & \\
\hline & f. & Pengadaan Barang dan Jasa & 521811 & & 33.130 .000 & 33.129 .900 & 100 \\
\hline & g. & Belanja Operasional Perkantoran & $\begin{array}{c}521111,521112,521113, \\
521114\end{array}$ & & 556.164 .000 & 556.087 .850 & 76.150 \\
\hline & h. & Belanja Jasa & 522191 & & - & - & - \\
\hline & i. & Belanja Pemeliharaan & $\begin{array}{c}\text { Seluruh Akun pada Subkomponen } \\
\text { Pemeliharaan Kantor }\end{array}$ & & 286.078 .000 & 281.284 .524 & 4.793 .476 \\
\hline & j. & Belanja Lainnya & 521219,522141 & & 10.512 .000 & 10.512 .000 & \\
\hline & & & jumlah & & & & 28.784 .945 \\
\hline
\end{tabular}

Sumber: Kantor Pelayanan Kekayaan Negara dan Lelang (KPKNL) Palangkaraya, 2020 